\title{
SM-ND ISOTOPY OF THE DYKES OF THE VORONTSOVSKOE GOLD-ORE DEPOSIT [NORTHERN URALS)
}

\author{
O. B. Azovskova, E. I. Soroka, M. Yu. Rovnushkin, N. G. Soloshenko \\ Institute of Geology and Geochemistry of UB RAS, Ekaterinburg \\ oazovskova@yandex.ru
}

The Vorontsovskoye gold-ore deposit (Northern Urals) generally corresponds to the Carlin-type. One of the deposit features is the presence of numerous dykes of mafic and middle chemical composition, of normal and increased alkalinity. Sm-Nd isotope studies for the first time confirmed the dykes formation age $340 \pm 35 \mathrm{Ma}$. These data can be indicative of the post-collisional stage of magmatism in this area. The positive $\varepsilon N d$ values suggest a probable abyssal magmatic source of $\mathrm{Nd}$.

Keywords: Sm-Nd isotopy, dykes, Vorontsovskoye gold-ore deposit, Carlin-type, Northern Urals.

\section{SМ-ND-ИЗОТОПИЯ ДАЕК ВОРОНЦОВСКОГО ЗОЛОТОРУДНОГО МЕСТОРОЖДЕНИЯ (СЕВЕРНЫЙ УРАЛ]}

\author{
О. Б. Азовскова, Е. И. Сорока, М. Ю. Ровнушкин, Н. Г. Солошенко \\ Институт геологии и геохимии УрО РАН, Екатеринбург \\ oazovskova@yandex.ru
}

Воронцовское Au-рудное месторождение (Северный Урал) по ряду основных характеристик отвечает карлинскому типу. Одной из особенностей месторождения является наличие на его площади многочисленных даек основного и среднего состава нормальной и повышенной щелочности. В результате проведенных изотопных исследований Sm-Nd-cистемы впер-

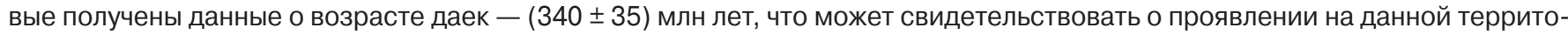
рии постколлизионного этапа магматизма. Положительные значения єNd указывают на вероятный глубинный магматический источник неодима.

Ключевые слова: Sm-Nd-изотопия, дайки, Воронцовское золоторудное месторождение, карлинский тип, Северный Урал.

The Vorontsovskoye gold deposit is located in the north of the Sverdlovsk region, near the city of Krasnoturinsk. Regionally, it is located in the eastern part of the Tagil megazone within the Auerbakh volcanoplutonic belt and belongs to the Turinsko-Auerbakh ore region. The deposit belongs to the gold-arsenic-sulfide formation and corresponds to the Karlinsky type by mineralogical and geochemical characteristics [2,5]. Mineralization is localized in the Lower Devonian volcanogenic-sedimentary formations of the Krasnoturinskaya suite; ore-hosting rocks include limestones, carbonate breccias, tuff siltstones, tuff sandstones and tuffites, metasomatically altered to varying degrees. In the eastern part of the region $(1.2 \mathrm{~km}$ from the Vorontsovskoe deposit), there is a multiphase Auerbakh massif of gabbro-diorite-granite formation, which dates back to the Early Devonian [1, 2] (Fig. 1).

A characteristic feature of the deposit is the presence of numerous dykes of intermediate and basic composition, forming a complex stockwork. Mineralogical, petrographic and petrochemical studies described dykes of normal alkalinity and moderately alkaline, including lamprophyres such as spessartite and kersantite [4]. According to the well-established concepts, it is believed that the dyke complex of the Vorontsovskoe deposit is genetically related to the Early Devonian subvolcanics and/or to the formations of the Auerbakh complex [2,3]. At the same time, no special studies have previously been carried out to determine the age of the dykes.

\section{Objects and research methods}

All analytical work was carried out at the laboratory of physical and chemical methods of study at the Geoanalyst Center of the IGG UB RAS. The study of the Sm-Nd isotope system and trial dating was carried out for 6 samples of rocks of normal and moderately high alkalinity, taken from dykes in the active quarry of the Vorontsovskoye deposit. Brief petrographic and petrochemical characteristics of the studied samples: Vor-4/17 - pyroxene-plagioclase porphyrite of basalt composition, normal alkalinity; Vor-14/17 - amphibole-plagioclase porphyrite of basaltic andesite composition, normal alkalinity; Vor-21$1 / 17$ - pyroxene-plagioclase porphyrite of basaltic composition, moderately alkalized; Vor-22/17 - rocks, in general, similar to Vor-21-1/17 (data of silicate ICP-MS analysis are not available); Vor-25/17 - porphyry-shaped monzogabbro, m/z-s/z; Vor-34-2/17 is lamprophyrespessartite (amphibole), petrochemically close to monzogabbro. The results of silicate analysis of the rocks of the dyke complex and the content of rare earth elements are shown in Table 1.

The rocks were studied by a scanning electron microscope (JSM-6390LV from Jeol with EDS analyzer). The studies showed that rare earth elements, including Sm and $\mathrm{Nd}$, were mainly associated with REE epidote (allanite). Lamprophyre-spessartite (sample Vor-34-2/17) was the most enriched and with different REE distribution nature (Fig. 2).

Для цитирования / For citation: Azovskova О. B., Soroka E. I., Rovnushkin M. Yu., Soloshenko N. G. Sm-Nd isotopy of the dykes of the Vorontsovskoe gold-ore deposit (Northern Urals). Vestnik of Geosciences. 2020. 9(309). P. 3-6. DOI: 10.19110/geov.2020.9.1. 


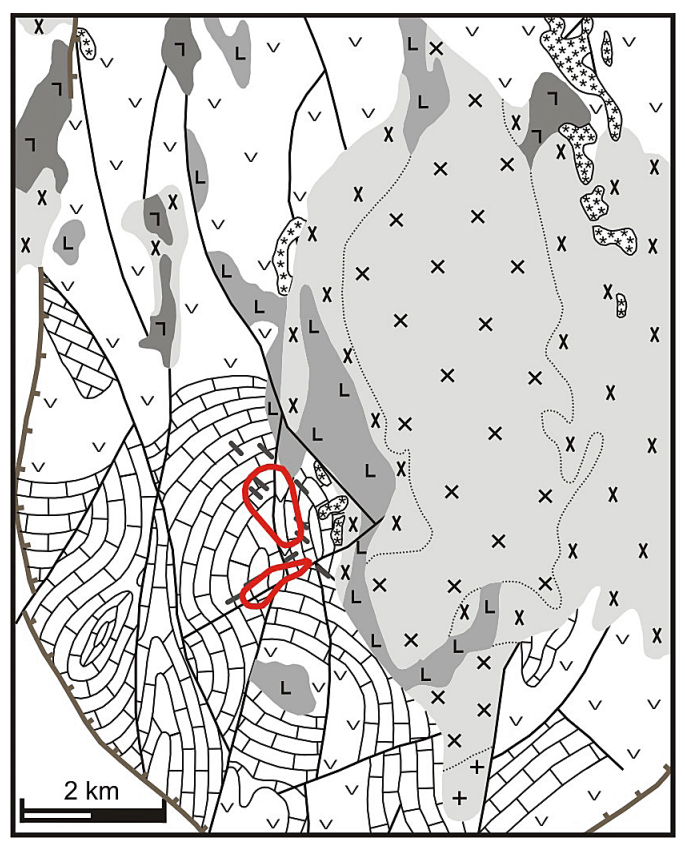

Fig. 1. Schematic geological map of the Vorontsovskoe deposit, according to [5]:

1 - turinskaya series $\left(S_{2}-D_{1}\right)$ : volcanites of trahybasalt-trahyandesite formation, rarely - tuffogenic-sedimental varieties and limestones; $2-3-$ krasnoturinskaya series $\left(D_{1}\right): 2-$ andesitic porphyries, tuffs, tuffaceous sandstones and siltstones; 3 - limestones; 4 - Lower Devonian subvolcanic rocks: diorite, andesite basaltic and dolerite porphyrites; $5-8$ - Auerbakh gabbro-diorite-granite complex $\left(\mathrm{D}_{1}\right)$ : 5 - granites, 6 - granodiorites, 7 - diorites, quartz diorites, 8 - gabbro, gabbrodiorites; 9 - dykes of diorite porphyries, lamprophyres, dolerites and gabbrodolerites; 10 - facial margins; 11 - faults bordering the structure; $12-$ other faults; 13 - skarns; 17 - outlines of the Vorontsovskoe quarries.

Рис. 1. Схематическая геологическая карта района Воронцовского месторождения [5]:

1 - туринская свита $\left(\mathrm{S}_{2}-\mathrm{D}_{1}\right)$ : вулканиты трахибазальт-трахиандезитовой формации, реже - туфогенно-осадочные разности и известняки; 2-3 краснотурьинская свита $\left(\mathrm{D}_{1}\right): 2-$ порфириты андезитовые, их туфы, туфопесчаники, туфоалевролиты, 3 - известняки; 4 - нижнедевонские субвулканические образования: диоритовые, андезибазальтовые и долеритовые порфириты; 5-8 - Ауэрбаховский габбро-диорит-гранитовый комплекс $\left(\mathrm{D}_{1}\right): 5$ - граниты, 6 - гранодиориты, 7 - диориты, кварцевые диориты, 8 - габбро, габбро-диориты; 9 - дайки диоритовых порфиритов, лампрофиров, долеритов и габбро-долеритов; $10-$ фациальные границы; 11 - разломы, ограничивающие структуру; 12 - прочие тектонические нарушения; 13 - участки скарнирования; 17 - контуры карьеров Воронцовского месторождения

Table 1. The chemical composition of the rocks (wt. \%) and REE content (ppm)

Таблица 1. Химический состав пород (мас. \%) и содержание РЗЭ (ppm)

\begin{tabular}{|c|c|c|c|c|c|}
\hline $\begin{array}{c}\text { Author’s № } \\
\text { Авторский № }\end{array}$ & $\begin{array}{l}\text { Vor-4/17 } \\
\text { Bop-4/17 }\end{array}$ & $\begin{array}{c}\text { Vor-14/17 } \\
\text { Bop-14/17 }\end{array}$ & $\begin{array}{c}\text { Vor-21-1/17 } \\
\text { Bop-21-1/17 }\end{array}$ & $\begin{array}{l}\text { Vor-21-1/17 } \\
\text { Bop-21-1/17 }\end{array}$ & $\begin{array}{l}\text { Vor-34-2/17 } \\
\text { Bop-34-2/17 }\end{array}$ \\
\hline $\mathrm{SiO}_{2}$ & 50.31 & 53.60 & 50.74 & 49.45 & 50.80 \\
\hline $\mathrm{TiO}_{2}$ & 0.74 & 0.66 & 0.54 & 0.67 & 0.84 \\
\hline $\mathrm{Al}_{2} \mathrm{O}_{3}$ & 16.09 & 18.50 & 18.52 & 18.82 & 15.85 \\
\hline $\mathrm{Fe}_{2} \mathrm{O}_{3}$ & 4.33 & 3.88 & 3.72 & 3.43 & 6.06 \\
\hline $\mathrm{FeO}$ & 6.8 & 4.9 & 3.6 & 3.9 & 1.0 \\
\hline $\mathrm{MnO}$ & 0.13 & 0.16 & 0.20 & 0.36 & 0.09 \\
\hline $\mathrm{MgO}$ & 6.62 & 2.86 & 4.25 & 3.92 & 7.43 \\
\hline $\mathrm{CaO}$ & 7.71 & 9.40 & 10.16 & 10.59 & 7.75 \\
\hline $\mathrm{Na}_{2} \mathrm{O}$ & 2.25 & 2.72 & 3.05 & 2.87 & 2.58 \\
\hline $\mathrm{K}_{2} \mathrm{O}$ & 0.91 & 1.53 & 1.37 & 2.24 & 2.29 \\
\hline $\mathrm{P}_{2} \mathrm{O}_{5}$ & 0.24 & 0.16 & 0.19 & 0.26 & 0.40 \\
\hline POI / Ппп & 3.6 & 1.3 & 3.4 & 3.2 & 4.9 \\
\hline Total / Сумма & 99.73 & 99.66 & 99.73 & 99.70 & 100.0 \\
\hline $\mathrm{S}$ & 2.10 & 0.07 & 1.08 & 0.34 & $\mathrm{H} / \mathrm{O}$ \\
\hline $\mathrm{La}$ & 8.220 & 7.313 & 6.474 & 7.415 & 32.566 \\
\hline $\mathrm{Ce}$ & 20.959 & 14.470 & 14.715 & 15.839 & 69.796 \\
\hline $\operatorname{Pr}$ & 2.840 & 1.913 & 2.061 & 2.136 & 9.218 \\
\hline $\mathrm{Nd}$ & 12.744 & 8.178 & 9.271 & 9.360 & 36.291 \\
\hline $\mathrm{Sm}$ & 3.341 & 2.023 & 2.403 & 2.345 & 6.085 \\
\hline $\mathrm{Eu}$ & 0.867 & 0.749 & 0.974 & 0.910 & 1.853 \\
\hline $\mathrm{Gd}$ & 3.731 & 2.278 & 2.821 & 2.641 & 4.412 \\
\hline $\mathrm{Tb}$ & 0.626 & 0.367 & 0.472 & 0.423 & 0.481 \\
\hline Dy & 4.294 & 2.477 & 3.241 & 2.906 & 2.737 \\
\hline Ho & 0.944 & 0.551 & 0.730 & 0.642 & 0.510 \\
\hline $\mathrm{Er}$ & 2.926 & 1.694 & 2.279 & 1.981 & 1.432 \\
\hline $\mathrm{Tm}$ & 0.429 & 0.253 & 0.343 & 0.298 & 0.203 \\
\hline $\mathrm{Yb}$ & 2.864 & 1.720 & 2.326 & 2.004 & 1.360 \\
\hline $\mathrm{Lu}$ & 0.449 & 0.278 & 0.365 & 0.317 & 0.208 \\
\hline$\sum \mathrm{REE}$ & 65.23 & 44.26 & 48.48 & 49.22 & 167.15 \\
\hline $\mathrm{Eu}^{\mathrm{N}} / \mathrm{Eu}^{\mathrm{N} *}$ & 0.75 & 1.07 & 1.15 & 1.12 & 1.05 \\
\hline
\end{tabular}

Note: $\mathrm{E}^{N *}=\mathrm{Eu}^{N} /\left(\mathrm{Sm}^{N+} \mathrm{Gd}^{N}\right) / 2$. REE content has done by ICP-MS method by mass spectrometer ELAN 9000 (operators N. V. Cherednichenko, L. K. Deryagina).

Примечание: $\mathrm{E}^{N *}=\mathrm{Eu}^{N} /\left(\mathrm{Sm}^{N+} \mathrm{Gd}^{N}\right) / 2$. Определение Р3Э проведено методом ICP-MS на масс-спектрометре ELAN 9000 (аналитики Н. В. Чередниченко, Л. К. Дерягина). 
The procedure for the chemical preparation of samples for measuring the concentrations and isotopic composition of $\mathrm{Sm}$ and $\mathrm{Nd}$ consisted of decomposing samples, isolating sum of rare earths, and separating $\mathrm{Sm}$ and $\mathrm{Nd}$. A sample was taken into a Savillex vial with a screw cap, a mixture of concentrated acids $\mathrm{HF}$ and $\mathrm{HNO}_{3}$ (3: 1) was added and heated in an oven at $120{ }^{\circ} \mathrm{C}$ for three days. Then the samples were evaporated to dryness, concentrated $\mathrm{HCl}$ was added and kept at $120^{\circ} \mathrm{C}$ for one day. At the moment of taking a sample, a mixed tracer ${ }^{149} \mathrm{Sm}-{ }^{150} \mathrm{Nd}$ was added to each sample. After dissection, the samples were subjected to chromatographic isolation of $\mathrm{Sm}, \mathrm{Nd}$ in two stages: with the isolation of rare earth elements on TRU-spec resin and
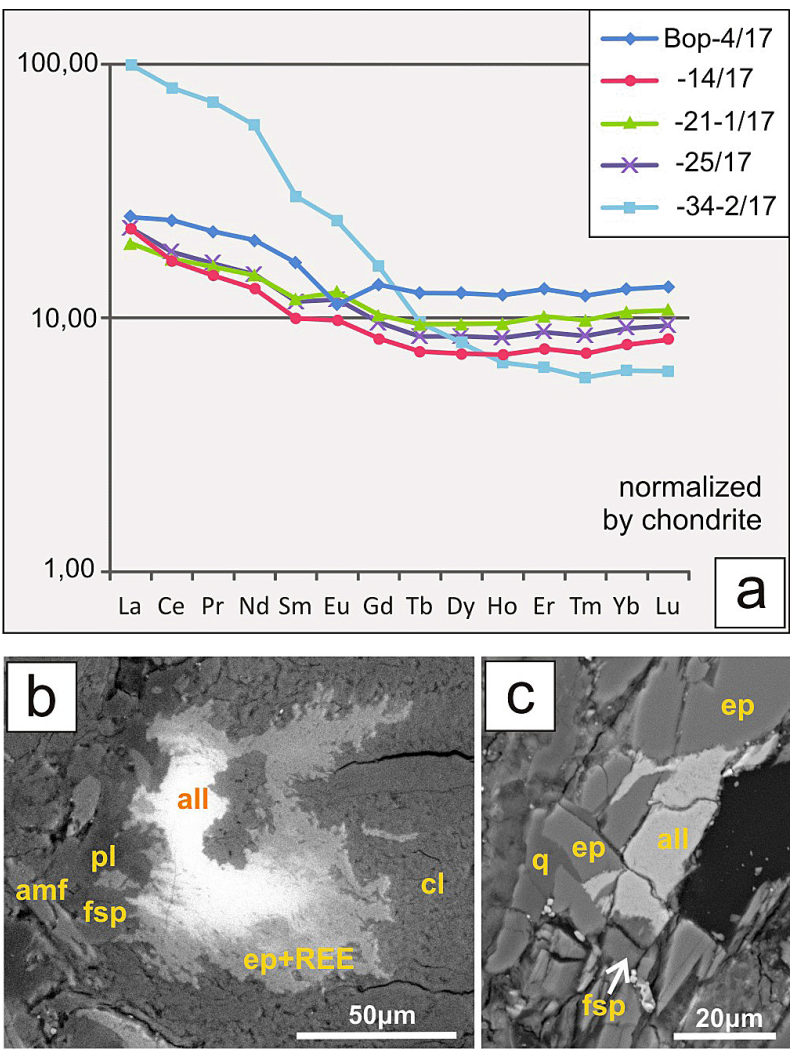

Fig. 2. REE distribution in dykes (a) and SEM photo of REE minerals, smp. Vor-34-2/17 (b, c).

Minerals: all - allanite, amf - amphibole (hornblende), cl - chlorite, ep - epidote, fsp - K-feldspar, $\mathrm{pl}$ - plagioclase, $\mathrm{q}$ - quartz

Рис. 2. Распределение РЗЭ исследованных дайках (а) и примеры основных минералов-концентраторов РЗЭ, обр. Вор$34-2 / 17(\mathrm{~b}, \mathrm{c})$.

Минералы: all - алланит, amf - амфибол (роговая обманка), $\mathrm{cl}$ хлорит, ep - эпидот, fsp - КПШ, pl - плагиоклаз, q - кварц the final separation on LN-spec resin [7]. The isotope ratios were measured by ICP-MS Neptune Plus MC (Thermo Finnigan) in a static mode from $3 \% \mathrm{HNO}_{3}$ solution. The uncertainty in the ${ }^{147} \mathrm{Sm} /{ }^{144} \mathrm{Nd}$ ratios is $0.3 \%(2 \sigma)-$ the average of 13 measurements in the BHVO-2 standard. The error in measuring the $\mathrm{Nd}$ isotopic composition in an individual analysis is up to $0.003 \%$. The isotopic ratios of neodymium are normalized to the ratio ${ }^{146} \mathrm{Nd} /{ }^{144} \mathrm{Nd}=0.7219$ according to the exponential law. Isochron parameters were calculated using ISOPLOT 3-v3.71 r5 program [6].

\section{Research results and discussion}

The results of $\mathrm{Sm}$ and $\mathrm{Nd}$ isotopic studies in the selected rocks of the dyke complex are shown in Table 2.

${ }^{147} \mathrm{Sm} /{ }^{144} \mathrm{Nd}$ values vary from 0.10408 to 0.19441 , and ${ }^{143} \mathrm{Nd} /{ }^{144} \mathrm{Nd}$ values vary from 0.512660 to 0.512860 . For the studied dyke samples, a calculation was made for the age of $340 \pm 35 \mathrm{Ma}$, with an initial ${ }^{143} \mathrm{Nd} /{ }^{144} \mathrm{Nd}=0.512436$ \pm 0.000036 . MSWD $=2.3$ (Fig. 3).

We also calculated $\varepsilon \mathrm{Nd}$ for the age of $340 \mathrm{Ma}$ (Table 2). The $\varepsilon N d$ values vary in a fairly narrow range, from 4.4 to 5.3. Positive $\varepsilon N d$ values indicate that the source of $\mathrm{Nd}$ could have been abyssal magma chambers.

The currently available data on the ages of intrusive rocks in the part of the Krasnoturinsko-Auerbakhovsky ore region close to the Vorontsovskoye deposit are shown in the diagram (Fig. 4)

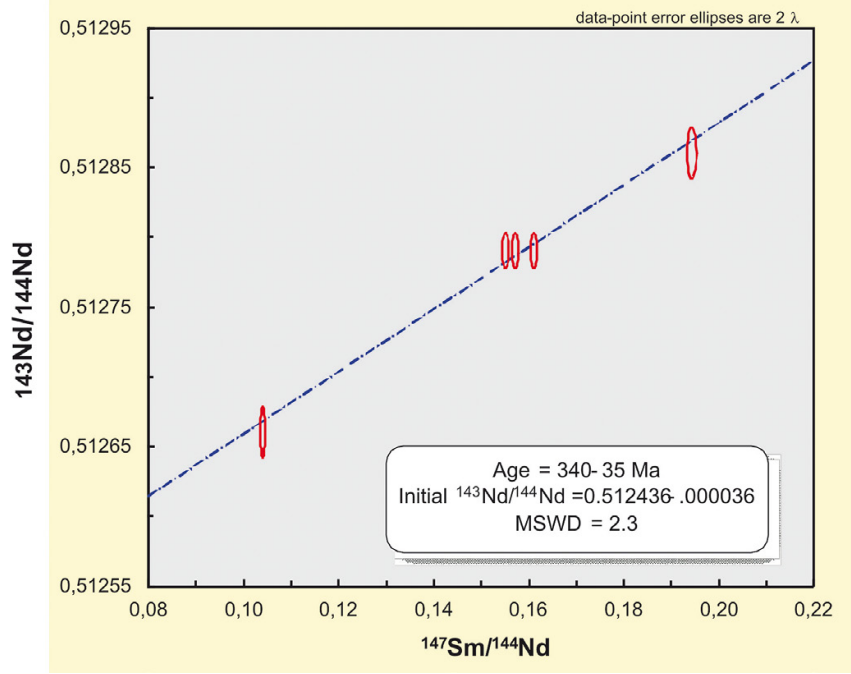

Fig. 3. Sm-Nd isotopic relations of the dykes of the Vorontsovskoe deposit

Рис. 3. Sm-Nd-изотопные отношения пород даек Воронцовского золоторудного месторождения

Table 2. Sm-Nd isotope composition of dyke complex rocks of the Vorontsovskoe deposit

Таблица 2. Sm-Nd-изотопный состав пород дайкового комплекса Воронцовского месторождения

\begin{tabular}{c|c|c|c|c|c|c|c}
\hline Sample / Проба & ${ }^{147} \mathrm{Sm} / 144 \mathrm{Nd}$ & 2SE, abs & $\left(143 \mathrm{Nd} /{ }^{144} \mathrm{Nd}\right)$ & $2 \mathrm{SE}, \mathrm{abs}$ & $\mathrm{Sm}, \mathrm{ppm}$ & $\mathrm{Nd}, \mathrm{ppm}$ & $\varepsilon \mathrm{Nd}(\mathrm{t})$ \\
\hline Vor-4/17 & 0.16334 & 0.00049 & 0.512835 & 0.000006 & 4.16 & 15.4 & 5.3 \\
Bop-4/17 & 0.15724 & 0.00047 & 0.512790 & 0.000010 & 2.5 & 9.6 & 4.7 \\
$-14 / 17$ & 0.16114 & 0.00048 & 0.512790 & 0.000010 & 3.02 & 11.3 & 4.5 \\
$-21-1 / 17$ & 0.19441 & 0.00058 & 0.512860 & 0.000015 & 1.81 & 5.6 & 4.4 \\
$-22 / 17$ & 0.15518 & 0.00047 & 0.512790 & 0.000010 & 2.88 & 11.2 & 4.8 \\
$-25 / 17$ & 0.10408 & 0.00031 & 0.512660 & 0.000015 & 8.2 & 48 & 4.5
\end{tabular}




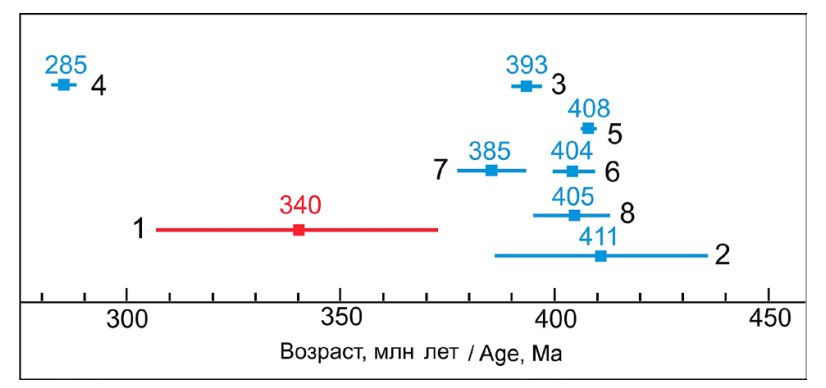

Fig. 4. The age of magmatic rocks at the area of Vorontsovskoe deposit (blue marks - Murzin et al., 2017):

1 - Sm-Nd, dykes of the Vorontsovskoe deposit (Northern quarry); $2-\mathrm{Sm}-\mathrm{Nd}$, biotite-pyroxene-amphibole diorite [5]; 3, 4-U-Pb, zircon, granodiorites (3) and the age of alteration (4) [2,7]; $5-\mathrm{U}-\mathrm{Pb}$, zircon, quartz diorite [1]; 6, 7- U-Pb, zircon, quartz diorite (6) and the age of alteration (7) [2, 7]; $8-\mathrm{Rb}$-Sr, different rocks [2, 7]

Рис. 4. Возрастные характеристики интрузивных пород района Воронцовского месторождения (синие знаки - по Мурзину и др., 2017):

$1-\mathrm{Sm}-\mathrm{Nd}$, дайки Воронцовского месторождения (Северный карьер); 2 - Sm-Nd, биотит-пироксен-амфиболовые диориты [5]; 3, 4- U-Pb, цирконы, гранодиорит (3) и время преобразования (4) [2, 7]; 5- U-Pb, циркон, кварцевый диорит [1]; 6, 7 $\mathrm{U}-\mathrm{Pb}$, цирконы, кварцевый диорит (6) и время преобразования (7) $[2,7] ; 8-\mathrm{Rb}-\mathrm{Sr}$, различные породы $[2,7]$

Various intrusive formations are known in the area of the deposit. According to [1], the isotopic composition of granodiorites of the Krasnoturinsky ore field indicates the abyssal nature of the fluid, and the $\mathrm{U}-\mathrm{Pb}$ age of zircon from quartz diorite sampled from an outcrop on the right bank of the Turya River is $407.7 \pm 1.6 \mathrm{Ma}$ (MSWD 1.5), which corresponds to the Early Devonian. According to [5], Sm$\mathrm{Nd}$ age of biotite-pyroxene-amphibole diorites, related to the Auerbakh gabbro-granite complex, is $411.7 \pm 25 \mathrm{Ma}$ (MSWD 0.36), ${ }^{143} \mathrm{Nd} /{ }^{144} \mathrm{Nd}=0.512395 \pm 0,000028$. As noted above, the dykes of the Vorontsovskoye deposit traditionally belonged to the Early Devonian subvolcanics and/ or formations of the Auerbakh complex; they have not been dated earlier. The studies, carried out by the authors of the paper, indicate a relatively young (Early Carboniferous) age of the dykes, which may indicate a later post-collisional stage of magmatism in this area.

The work was performed within the theme No. AAAA-A18-118052590028-9 of the State Assignment of the IGG UB RAS.

\section{References}

1. Grabezhev A. I., Ronkin Yu. L., Puchkov V. N., Gerdes A., Rovnushkin M. Yu. Krasnoturinskoe medno-skarnovoe rudnoe pole (Severny Ural): U-Pb vozrast rudokontroliruiushchikh dioritov i ikh mesto v skheme metallogenii regiona (Krasnoturyinsk copperscarn ore field (Northern Urals): U-Pb age of ore-controlling diorites and their place in the metallogeny of the region). Doklady Earth Sciences, 2014, V. 456, No. 4, pp. 443-447.

2. Fershtater G. B. Rannedevonski intruzivny magmatizm Urala - indikator perelomnogo etapa v paleozoiskoi istorii podvizhnogo poiasa (Early-Devonian intrusive magmatism of the Urals as indicator of critical stage Paleozoic history mobile belt). Litosfera. (5), 2015, pp.5-29.

3. Krasnobaev A. A., Fershtater G. B., Bogomolov E. S., Larionov A. N., Berezhnaja N. G. Auerbahovski granitoidny massiv: tcirkony, vozrast, polikhronnost (Auerbah granitoid massif: zircons, age, polychrony). Ezhegodnik-2006. Ekaterinburg, IGG UB RAS, 2007, pp.191-196.

4. Murzin V. V., Sazonov V. N., Ronkin Yu. L. Model formirovaniia Vorontcovskogo zolotorudnogo mestorozhdeniia na Urale (karlinskii tip): novye dannye i problemy (Model for formation of Vorontsovskoe gold deposit in the Urals (Carlin type): new data and problems). Litosfera, (6), 2010, pp. 66-73.

5. Murzin V. V., Naumov E. A., Rovnushkin M. YuAzovskova., O. B. ${ }^{40} \mathrm{Ar} /{ }^{39} \mathrm{Ar}$ vozrast zoloto-myshiakovy $k \mathrm{kh}$ rud Vorontcovskogo zolotorudnogo mestorozhdeniia (Severny Ural) ${ }^{40} \mathrm{Ar} /{ }^{39} \mathrm{Ar}$ age of gold-arsenic ores Vorontsovskoe gold deposit (the Northern Urals)). Litosfera, 2017, No. 3, pp. 127-132.

6. Ronkin Yu. L., Petrov G. A., Lepikhina O. P. Pretcezionnoe Sm-Nd izotopnoe datirovanie Auerbahovskogo gabbro-granitovogo kompleksa (Severny Ural) (Precision Sm-Nd isotope dating of Auerbah gabbro-granite complex (Northern Urals)). Isotope systems and age of geological processes. Proc. IV Rusasian Conf. V. II, St. Petersburg, IP Katalkina Publ., 2009, pp. 122-124.

7. Sazonov V. N., Murzin V. V., Grigoriev N. A., Gladkovsky B. A. Endogennoye orudeneniye devonskogo andezitoidnogo vulkano-plutonicheskogo kompleksa (Ural) (Endogenetic ore mineralization of the Devonian andesitoid volcano-plutonic complex (Ural)). Sverdlovsk, 1991, 184 p.

8. Azovskova O. B., Rovnushkin M. Yu, Soroka E. I. Petrochemical features of the dyke complex of the Vorontsovskoye gold-ore deposit (Northern Urals). Proceedings of Ural mining university, 2019, 1(53), pp.18-27.

9. Murzin V. V., Naumov E. A., Azovskova O. B., Varlamov D. A., Rovnushkin M. Yu., Pirajno F. The Vorontsovskoe Au$\mathrm{Hg}-$ As ore deposit (Northern Urals, Russia): Geological setting, ore mineralogy, geochemistry, geochronology and genetic model. Ore Geology Reviews, 85, 2017, pp. 271-298.

10. De Paolo D. J. Neodinium isotope geochrmistry: an introduction. Heidelberg: Springer-Verlag, 1988, 187 p.

11. Pin C., Zalduegui J. E. S. Analytica Chimica Acta. V. 339. 1997, pp. 79-89.

Поступила в редакцию / Received 22.09.2020 